\title{
Anna BUCHALCZYK
}

\section{PITYMYS SUBTERRANEUS (DE SELYS-LONGCHAMPS 1835) UNDER LABORATORY CONDITIONS}

\section{PITYMYS SUBTERRANEUS (DE SELYS-LONGCHAMPS 1835) IW WARUNKACH LABORATORYJNYCH}

The breeding of Pitymys subterraneus has been carried on at Białowieża uninterruptedly since the autumn of 1957 up to the present time. The initial material was obtained from the Białowieża National Park.

The animals are accommodated in special breeding places consisting of basements lighted by large windows, the ventilation of which is ensured by changing the air frequently. Temperature is maintained within the required limits by means of central heating, while fluorescent lighting supplies additional light. The mean temperature is $18-20^{\circ} \mathrm{C}$, , and the minimum never falls below $15^{\circ} \mathrm{C}$. Atmospheric humidity is maintained between the limits - $70-80 \%$. During the cold part of the year the place is aired thoroughly once a day for an hour (temperature during airing falls temporarily to $1-2^{\circ} \mathrm{C}$ ), while the window is kept open during the summer. If humidity decreases unduly the floor is sprinkled with water.

The animals live in cages measuring $15 \times 25 \times 40 \mathrm{~cm}$., so placed as to ensure that a more or less uniform light reaches them. The cages slope forwards in order to permit fluids to flow out on to the run in front of the cages

The cages themselves are made of tin-plate and netting, divided into nest and run sections. The wooden cages used until mid - 1958 proved unsuitable as they were quickly dirtied, and also because the animals gnawed through them and escaped. The metal cages are easier to keep clean, but the sheeting rusts quickly and they are somewhat "cold".

Peat is used as litter, and hay for the nests. Vessels containing water and food ad libitum are placed in the run, and an additional drinking vessel is hung on the netting of the run. The run is cleaned out every day and the remains of food removed. The nest is cleaned out and hay changed once a week, while the cage is changed every six months for purposes of desinfection. If the animals fall ill or die the cage is changed.

The basic food of the animals consists of oats and root foods such as white or red beets, potatoes (less readily eaten), carrots and parsnips (the latter being their favourite food). Oats are given to the adults in grain form, and rolled oats to the young animals. Depending on the condition of the animals one or more of the following are added to their food: creamed baker's yeast, vitamin E, oil seed, milk. In the spring and summer green foods are added, while sprouting oats and thin branches of ash, willow or aspen are given in the autumn. Fruit or mushrooms are given from time to time. The animals tend to make stores of their food, which are removed when cleaning out the nests. 
These small rodents are kept in pairs in the cages, and the young are separated from their parents after weaning, marked, segregated according to sex and kept $4-6$ in separate cages until they are paired. Where possible unrelated individuals are mated. Inbreeding is only used for selection purposes.

Contrary to other species kept in captivity, it was found that even two successive litters can be left with the mother without danger of the younger litter being eaten or starved to death by the members of the older litter. Frequently the mother shares the nest with the newly-born young, the male and the young animals born in the previous litter. The female never bites when the nest is being examined, and at most merely attempts to carry one of the young away and hide it. The animals, through being treated gently from birth and often picked up, never attempt to bite.

It is, however, not advisable to keep the growing animals too long together. If there are several males in such a group, the weaker ones are usually bitten or starved to death.

During the study period a total of 19 individuals was introduced, which had been captured wild, as shown in the table below:

$\begin{array}{cccccc} & 1957 & 1958 & 1959 & 1960 & \text { Total } \\ \sigma^{\top} \sigma^{\times} & 2 & 1 & 4 & 1 & 8 \\ \uparrow \subsetneq & 1 & 5 & 3 & 2 & 11\end{array}$

Females caught in their wild state reproduced freely and founded the lines existing up to the present. Over a period of three years there were 30 females producing young. Up to September 1960 a total of 278 individuals was obatined by breeding, counting the specimens taken from their mother. The number of young per litter was most frequently $3(48.9 \%$ of births), then $2(25.2 \%), 4(16.1 \%), 1$ only $-(9.1 \%$ ) and 5 (in one case only $-0.7 \%$ ) a sum total of 143 births. A total of 13.3 young are borne by one sexually active female, of which 10.96 are reared. The figures per litter are 2.7 born and 2.28 reared.

The number of litters produced by one female are given below:

$\begin{array}{lllllllllr}\text { number of } f+ & 7 & 4 & 5 & 3 & 3 & 3 & 2 & 2 & 1 \\ \text { number of litters } & 2 & 3 & 4 & 5 & 6 & 7 & 8 & 9 & 10\end{array}$

Sex was determined in a total of 132 reared young animals from 56 litters. The ratio of males to females was $69: 63$ (1.05:1). The slight preponderance of males would appear to result from the fact that certain of the litters were rendered incomplete by the young dying before sex was determined.

Ten of the females constantly reproduced, so that they had a successive series of litters at intervals shorter than every four weeks. Coitus must therefore have taken place during the post-natal oestrus. Several of the females had an interval of $1-2$ months between litters. This proves either that post-natal oestrus did not take place or that coitus was without effect, and that they did not become pregnant until after they had finished nursing their young. About $30 \%$ of the females had a longer interval between litters of from $2-8$ months, none of them, however, gave the impression 
of being either ill or exhausted - on the contrary, they appeared to be in good condition. As no vaginal smears were made during this period it is not possible to state whether oestrus occurred, or whether so long an interval in the normal sexual cycle was due to other causes.

I had imagined that a larger number of young in the litter might affect the length of interval between following litters. It became obvious, however, that irrespective of whether the female had, for example, 1 or 4 young, the next litter might quite as likely be born 22 days or 29 days later. I have given below the length of intervals between successive litters in cases in which post-natal oestrus occurred:

$$
\begin{array}{lrrrrrrr}
\text { number of days } & 20 & 21 & 22 & 23 & 24 & 25 & 26 \\
\text { number of } q \uparrow & 2 & - & 7 & 17 & 31 & 16 & 5
\end{array}
$$

Males in which the testes were mature, and females in which the entrance to the vagina was open, were placed together in pairs. After being put together the female usually gave birth to young $24-27$ days later. It would appear from this that young over 100 days old are by then fully capable of reproduction. Wasile w ski (1960) assumes that maturation takes place more rapidly under field conditions. This is also indicated in the work of Langenstein-Issel (1950) who found that males bred by her matured after 7-8 weeks (maturity was determined by the weight of the testes).

Pitymys subterraneus is relatively long-lived in captivity. The oldest of our males were 26 months old, and judging by their exterior appearance did not reveal any symptoms of senescence. A male taken from natural conditions (already sexually mature) lived 32 months in captivity, and therefore died at the age of at least 34 months. The females did not attain so great an age under artificial breeding conditions. It is of course not impossible that the female is shorter-lived in general than the male, possibly as the result of intensive reproduction. The females we kept in captivity never lived longer than about 22 months, but they maintained their reproductive capacity to the end, or almost to the end, of their lives.

In the period from March 15th to April 15th, 1960 we had a period of high mortality among the suckling young and the young separated from their parents. The diseased individuals exhibited symptoms of high temperature (fever) accompanied by severe diarrhoea. Death took place $2-3$ days later. In all 40 specimens died, then the disease ceased of its own accord. It must, however, be emphasised that none of the adult animals died.

\section{REFERENCES}

L a ngenste in-Iss e 1, B. - Biologische und ökologische Untersuchungen über die Kurzohrmaus (Pitymys subterraneus de Sély s-Long$\mathrm{c} \mathrm{h}$ a m p s). Pflanzenbau u. Pflanzenschutz, 1,4: 145-183, 1950. W a sile w s k i, W. - Angaben zur Biologie und Morphologie der Kurzohrmaus, Pitymys subterraneus (de Sély s-Long ch a m ps 1835). Acta Theriol., 4: 185-247. Bialowieża, 1960 .

Mammals Research Institute in Białowieża, Polish Academy of Sciences. 